\title{
原著
}

\section{透析をしながら働く中年期男性における 生活史の編みなおし尺度の開発}

\author{
内田雅 子*

\section{Development of the Scale for Biography Recasting in Middle-aged Working Men on Chronic Dialysis}

\author{
Masako Uchida \\ Doctoral candidate, Japanese Red Cross College of Nursing
}

\begin{abstract}
The purpose of this study was to develop the Scale for Biography Recasting in Middle-aged Working Men on Chronic Dialysis. Biography recasting of chronic dialysis patients refers to redirection of future plans following the major life change. The chronic dialysis patients need to deal with chronic nature of their illness and its treatment as well as to cope with social and psychological effects of these. Biography recasting is necessary, therefore, for them to reconstruct fulfilling life.

Corbin \& Strauss's concept of illness trajectory was drawn upon in the scale construction. In Study 1, twelve dialysis patients were interviewed in order to select items to be included in the scale. The content validity of the scale was then examined by using another group of subjects. In Study 2, the reliability and the face validity of the scale were tested. Study 3 tested the reliability and the construct validity. Five factors of the scale emerged in the factor analysis with varimax rotation. Cronbach's alpha coefficient obtained for the five subscales and the scale as a whole ranged from .73 to .83 , indicating a good reliability of the scale. The factor structure of the scale seems generally to agree with Corbin and Strauss's conceptualization of illness trajectory, and hence the scale appears to have a good construct validity.

The scale provides a useful tool for men undergoing chronic dialysis to understand how they are going about in readjusting their lives after the major life change.

The further refinement of the scale is, however, necessary.
\end{abstract}

\section{要旨}

本研究は，透析をしながら㗢く中年期男性の生活史の編みなおしの程度を測定する尺度を 開発し，その信頼性および妥当性を検定することを目的とした．本研究の概念枠組みは, Corbin \& Straussの説く病みの軌跡における生活史概念に基づいている. 生活史の編みな

*日本赤十字看護大学大学院看護学研究科博士後期課程 
おしとは，慢性病および療養法の実践に伴う身体的，心理社会的変化を乗り越えて病気を 人生に組み込みながら，他者との関係性を調整することである，それは同時に，生活史をそ の人らしい満足感のある社会生活を目指して, 主体的に方向づけることをさしている.

研究 1 では, 面接調査を行い 2 下位尺度 31 項目からなる尺度原案を作成した. 20 名の研 究者を被験者として尺度原案の内容妥当性を検定し，4下位尺度 19 項目に修正した。つぎ に研究 2 において，36名の透析者を被験者として尺度の信頼性および表面妥当性を検定し， 4 下位尺度 17 項目に修正した. 最後に研究 3 において, 89名の透析者を被験者として尺度 の信頼性を検定し, 構成概念妥当性を検討した。 最終尺度は, 因子分析結果を基に再構成 し5下位尺度 15 項目とした。 尺度全体および5下位尺度の信頼性は，内部整合性において Cronbach's $\alpha .73-.83$ で確保された，構成概念妥当性は，因子妥当性の確認および因子分 析前の理論的構造との比較によって, ある程度の整合性が支持された.

本尺度は, 透析者が人生という文脈において生じた生活史上の課題に, どのような方向づ けで取り組んでいるのかを理解する一助となるであろう.

今後, 下位尺度を検討したうえで尺度全体を洗練させていく必要がある.

\section{I . はじめに}

近年医療技術の進歩によってわが国の透析者 数は急速に増加しており，1994年現在，15万 人近くに達している. そのうち社会復帰をして いるものは全体の7割で, 60 才未満男性では 8 割を占めている ${ }^{1,2)}$.

透析者は週 10〜 15時間の透析療法とそれに 伴う水分・食事制限, 運動制限, 内服療法など 複雑な療養法を実践していかねばならない. と りわけ中年期男性の場合, 日常生活のなかで療 養法を実践し, さらに仕事や子供の養育など周 囲に期待される役割を果たし, 生活の社会経済 的安定を維持するという多くの課題を負つてい $ろ^{3,4)}$. したがって, 透析をしながら働く中年期 男性 (以下, 透析者とする) は, 慢性病のもたら す様々な制約のなかで自己の社会的役割をいか に果たすかという, 矛盾や葛藤の多い生活史上 の課題に度々直面すると推測される.

Corbin \& Strauss(1988)によれば，このよ うな生活史上の課題に主体的に取り組むことが, 慢性病を受容するプロセスともなり，その人の 生活の質を維持することにつながるという5). 透析者の心理社会的問題に関する先行研究の多 くは, 心理社会的影響の認知, あるいはコーピ ング様式の選択に焦点を当てている ${ }^{6 \sim 8)}$. それ らは, デモグラフィック変数との関連, あるい
は透析に伴う自己管理の compliance, adherence, 生活の質 (quality of life)などのアウト カムとの関連が検討されている ${ }^{9 \sim 13)}$.

しかし, 生活史という文脈における心理社会 的問題, すなわち生活史上の課題としてはほと んど検討されていない. 個人を尊重した看護介 入を吟味するには, 生活史に関する情報が不可 欠である.したがって看護においては慢性病に 伴う心理社会的問題は, 透析者の生活史上の課 題に対する主体的な取り組み, という視点から 捉え直した検討が必要であると考える.

そこで本研究は, 透析者における生活史上の 課題への主体的な取り組みを, 生活史の編みな おしの程度として測定する尺度を作成し，その 信頼性と妥当性を検討することを目的とした。

\section{II. 本研究の概念枠組みと操作的定義}

\section{1. 概念枠組み}

Corbin \& Straussの説く病みの軌跡とは, 疾患コースに関与する慢性病者とその家族や医 療者によってなされる全体的な仕事の組織と, 関与する人々への影響を意味している ${ }^{5,14,15)}$. そのなかで慢性病者が軌跡を管理するというこ とは，予測不能の事態に最善を尽くして対処す るということである.

それは, 慢性病者が人生という文脈において 過去を振り返り, 慢性病が将来に及ぼす帰結を 
ある程度予期し，病いの経験に意味づけをする. その意味を指針として，自分らしい満足のある 生活を目指して主体的に方向づける行為を展開 することをさしている.

すなわち透析者はこのような生活史の編みな おしによって，病みの軌跡を主体的に方向づけ ることが可能になると考えた。

\section{2. 生活史の編みなおしの操作的定義}

生活史の編みなおしとは, 慢性病によって断 続化した人生に，ある程度のコントロールとバ ランスを取り戻すことを目的としている．つま りその人らしい満足感のある社会生活を送るた めに，病気を生活史にどのくらい組み込んでい るのか，他者との関係性をどのくらい調整して いるのかを行為の程度によって測定するもので ある，生活史の編みなおしは，自分らしく生活 するための調整，他者と共に生活するための調

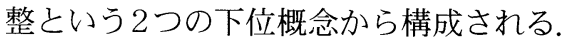

自分らしく生活するための調整とは, 慢性病 者としてできるだけ身体の良好さを保つことを 指向した行為と, 家庭や職場における役割と責 任を果たし自分らしさとしての満足を得ること を指向した行為の兼ね合いを調整することをさ す。両者の行為はそれぞれの目的達成を妨げた り助長したりする側面をもつ.

他者と共に生活するための調整とは，慢性病 者が対面的相互行為場面において病者としての 一側面を見せることで，彼の仕事仲間，友人ら との関係に生じうる影響をいかに調整して社会 関係を存続するかという行為をさす。つまり病 いの, 目に見えない集団特有の社会文化的意味, あるいは目に見える身体的変貌や療養法の実践 という事象が, 他者との関係性にどのような変 化を引き起こすかを考慮して, 活動や振る舞い を調整することである.

\section{III. 研 究 1}

\section{1. 目 的}

「生活史の編みなおし」尺度原案を作成し，そ の内容妥当性を検討する.

\section{2. 方 法}

\section{1 ) 面接調査}

1996年6月 1 ～ 25 日に都内の患者会および透 析施設 2 ヶ所において, 生活史編みなおしに関 する質的デー夕を得るために面接調査を実施し た. 対象者は，透析導入後半年以上経過してお り，何らかの職業に就いている35〜55歳前後 の男性とした. 調査の同意が得られた 12 名に対 して, 半構成的面接を行った.

\section{2）尺度原案の内容妥当性の検討}

1996 年 8 月 14 日〜 28 日に尺度原案の内容妥 当性を検討することを目的として, 調査を実施 した。対象者は, 慢性病の看護または保健医療 面に精通している大学院修士課程修了以上の研 究者とした。対象者に調査の主旨，無記名での 結果取り扱い, 調査は強制でなく調査主旨への 賛同によって成立すること，などについての説 明を添えて調査用紙を郵送した，2つの下位尺 度に関する説明資料と，尺度原案の質問項目を ランダムに並ベたリストを提示し，全質問項目 をそれぞれ該当する下位尺度に分類してもらつ た. また，分類できない項目や構成概念の問題 点について指摘してもらった.

\section{3. 結 果}

面接調査における対象者 12 名の平均年齢は $57.7 \pm 8.9$ 歳, 維持透析の平均年数は $8.8 \pm 6.2$ 年, 常勤給与職 2 名, 雇用者 8 名, 退職者 2 名で あった。

尺度原案作成は，まず先行研究および文献か ら得た内容から演繹的に構成概念を抽出した. 病いの経験を生活史に組み込む部分については, Strauss (1988) らが示した生活史的仕事 ${ }^{5)}$ を基 に，朝倉(1987)が示した職業生活再建の構造と その要因 ${ }^{4)}$ を含めて, 下位尺度を構成した。 他 者との関係性における調整については, Goffman (1963)の共在場面の相互行為理論 ${ }^{16)}$ に基 づいて，下位尺度を構成した。

つぎに，面接調査から得た質的デー夕を吟味 し帰納的に構成概念を修正し，合計73の質問項 目を抽出した. それら項目を整理検討し〈自分 らしく生活するための調整〉および〈他者と共 
に生活するための調整〉の 2 下位尺度 31 項目か らなる，生活史の編みなおし尺度原案を構成し た.

内容妥当性の検討は，計 20 名の回答を基に分 析を行った. 各質問項目があらかじめ本研究で 分類していたとおりに振り分けられたかどうか を，回答の一致度により検討した。一致度が $60 \%$ 以上項目は 31 項目中 20 項目であった. 回答の $20 \%$ 以上が問題のある項目としたのは 5 項目であった．また，2つの構成概念が大きす ぎ，明確に区別できないとの指摘が多く，尺度 の尺度構成を小さくした. 〈病いと共に生活する ための調整〉と〈他者と共に生活するための調整〉 を上位尺度とし，それぞれに下位尺度を新たに 設定した. 上位尺度の〈病いと共に生活するため の調整〉は,〈病いと共存するための価值観の転 換〉,〈病いの変化に対応した生活の編成〉の 2 下 位尺度 12 項目に設定し直した。 もう一方の上位 尺度〈他者と共に生活するための調整〉は，〈関係 性保存のための手段的調整〉,〈社会的相互作用 への情緒的調整〉の 2 下位尺度 7 項目に設定し直 した，項目の表現においては，回答の偏向を生 じる可能性が強い, あるいは項目の内容を適切 に表現できていないなど, 修正の必要性が指摘 された項目について検討した。 その結果, 修正 した尺度原案は4下位尺度19項目となった。

\section{IV. 研 究 2}

\section{1. 目 的}

「生活史の編みなおし」尺度の信頼性および表 面妥当性を検討する.

\section{2. 方 法}

1996年 9 月 19 日〜 10 月 7 日に本尺度全 19 項 目を用いて調査を実施した。首都圏の透析施設 3 ヶ所において, 透析導入から半年以上を経過 し何らかの職業に就いている35～55歳の男性 を選定し，かつ研究の主旨説明に同意の得られ たものを対象とした. 質問項目に対する回答は, 項目に示された内容に対して自分がどのくらい あてはまるかについて，5件法で評定を求めた. 非常にあてはまる (5点)〜全くあてはまらない (1点)として得点化した. 逆転項目 (2 項目)につ
いては得点を逆転化した。 分析方法は, 各項目 の記述統計量, 項目間相関係数, 尺度全体の信 頼性係数 (Cronbach's $\alpha$ ) および表面妥当性を 検討した。統計処理には統計ソフトHALBAU を用いた。

\section{3. 結 果}

有効回答者 36 名 (回収率 70\%) を分析対象と した. 対象の内訳は平均年齢 $47.1 \pm 5.3$ 歳, 平 均透析導入年齢 $39 \pm 9.2$ 歳, 平均維持透析年数 $8 \pm 7.7$ 年であった. 大多数が常勤職で, うち 25名(69.4\%)が公務員若しくは会社員であった.

全 19 項目の信頼性係数 (Cronbach's $\alpha$ ) は.70で, 各下位尺度は.58〜.79であった. 尺度 内項目間相関係数については, 他の項目との相 関係数が $\mathrm{r}<|.30|$ に満たないものはなかったが, 第1主成分負荷量が|.20|に満たないものが4 項目 あった. しかし下位尺度の構成概念に必要な項 目と考えたものはそのまま残し，表面妥当性の 点から問題がある 2 項目を削除した. 最終的に 4 下位尺度 17 項目とした. 修正した尺度の信頼性 係数は 17 項目全体が.68で，4下位尺度は.57 〜.79であった(表7).

残つた 17 項目について, 内容の曖昧な項目や, 行為というより認知・結果の状態を表している 項目，また対象者にわかりにくい表現と指摘さ れた項目を中心に表現を修正した.

\section{V. 研 究 3}

\section{1. 目 的}

「生活史の編みなおし」尺度の信頼性および構 成概念妥当性を検討する.

\section{2. 方 法}

1996 年 10 月 28 日 11 月 30 日に都内 8 ヶ所 の透析施設において, 本尺度全 17 項目を用いて 調查を実施した. 対象者の選定条件および回答 方式は, 研究 2 と同様に実施した. 分析方法は まず，項目分析として各項目の記述統計量と各 項目間のピアソン積率相関係数を検討した後, 主成分分析およびバリマックス回転による因子 分析を行つた，つぎに尺度の最終的な信頼性を 検討するために, 因子分析の結果を基に尺度の 
再構成を行い，尺度全体および各下位尺度につ いて信頼性係数 (Cronbach’s $\alpha$ ) を検定した. そして尺度の構成概念妥当性を検討するために, バリマックス回転後に得られた標準因子得点と 理論的に関わりのある変数について，ケンドー ル順位相関係数および一元配置分散分析を行っ た ${ }^{17)}$.

生活史の編みなおしと理論的に関係が予測さ れるのは，生活史に関わる客観的主観的指標で ある.したがって, 年齢, 婚姻 - 同居家族, 最 終学歴, 職歴, 病歴, 現在の就労状況および社

表 1 分析対象者の背景 $(n=89)$

\begin{tabular}{|c|c|c|c|}
\hline & & $\mathrm{n}$ & $\%$ \\
\hline \multirow[t]{4}{*}{$\begin{array}{ll}\text { 年 齢 層 } \\
\end{array}$} & $35 \sim 39$ 歳 & 6 & 6.7 \\
\hline & $40 \sim 44$ 歳 & 18 & 20.2 \\
\hline & $45 \sim 49$ 歳 & 35 & 39.3 \\
\hline & $50 \sim 56$ 歳 & 30 & 33.7 \\
\hline \multirow{5}{*}{$\begin{array}{l}\text { 原疾患発見 } \\
\text { ～透析導入 }\end{array}$} & $0 \sim 1$ 年 & 24 & 27.0 \\
\hline & $2 \sim 5$ 年 & 14 & 15.7 \\
\hline & $6 \sim 10$ 年 & 17 & 19.1 \\
\hline & $11 \sim 43$ 年 & 29 & 32.6 \\
\hline & 除外：移植経験者 & 5 & 5.6 \\
\hline \multirow[t]{2}{*}{ 透析回数 / 週 } & 2 回 & 7 & 7.9 \\
\hline & 3 回 & 82 & 92.1 \\
\hline \multirow[t]{3}{*}{ 婚姻状況 } & 既婚 & 72 & 80.9 \\
\hline & 未婚 & 15 & 16.9 \\
\hline & 離婚 & 2 & 2.2 \\
\hline \multirow[t]{2}{*}{ 家族 } & 同居 & 81 & 91.0 \\
\hline & 一人暮らし & 8 & 9.0 \\
\hline 職歴 & 継続 & 65 & 73.0 \\
\hline \multirow[t]{4}{*}{ （重複回答） } & 病気で離職／解雇 & 11 & 12.4 \\
\hline & 初めて働く & 2 & 2.2 \\
\hline & 自営業を開業 & 9 & 10.1 \\
\hline & その他 & 5 & 5.6 \\
\hline \multirow[t]{4}{*}{ 就労状況 } & 自営業 & 23 & 25.8 \\
\hline & 常勤給与職 & 53 & 59.6 \\
\hline & パート・アルバイト & 5 & 5.6 \\
\hline & その他 & 8 & 9.0 \\
\hline \multirow[t]{3}{*}{ 就労日数 / 週 } & $1 \sim 5$ 日 & 58 & 65.2 \\
\hline & $6 \sim 7$ 日 & 30 & 33.7 \\
\hline & 無回答 & 1 & 1.1 \\
\hline \multirow[t]{6}{*}{ 最終学歴 } & 中学校 & 6 & 6.7 \\
\hline & 高等学校 & 25 & 28.1 \\
\hline & 高専 & 2 & 2.2 \\
\hline & 専門学校 & 6 & 6.7 \\
\hline & 4 年大学 & 47 & 52.8 \\
\hline & 大学院 & 3 & 3.4 \\
\hline
\end{tabular}

会生活満足度に関する変数をとりあげ，これら を個人特性変数とした。社会生活満足度は，仕 事の満足度, 職場の理解度, 職場の人間関係満 足度，身体が辛くて仕事を辞めたくなる程度， 生計に対する 5 ～件法の主観的評価である. 最 後に，再構成した下位尺度間の関係を理論的に 設定した尺度と比較するために，ピアソン積率 相関係数および重回帰分析を行った.

\section{3. 結 果}

有効回答者 89 名 (回収率 $92 \%$ ) を分析対象と した。対象の内訳は, 平均年齢 $47.4 \pm 4.9$ 歳, 透析導入平均年齢 $39.0 \pm 7.5$ 歳, 維持透析平均 年数 $8.6 \pm 6.7$ 年，同居家族有り $91 \%$ ，既婚者 80.9\%であった。職種は会社員 $48.3 \%$ ，自営業 $25.8 \%$ が最も多く，全体の $65.2 \%$ 給与職であ つた。病気が原因で職歴の変更を経験したもの は21.3\%であった(表1)。社会生活，特に職業 生活に関する満足度は，全般的に中等度からや や高めの満足度を示していた(表2).

\section{1 ）因子構造}

項目間相関において，相関係数が|.30|末満で あった2項目を除外して，15項目について主成 分分析を行った. 全体に対する5因子の累積寄 与率は62.6\%であった(表 3$)$ そてして，バリマク ス回転後の因子負荷量|.40|以上を示した項目の 内容を参考に各因子を解釈した.

因子 I は，慢性病を日常生活に組夕込む過程 における，家族の協力体制の確立や生活の新た な組織化と解釈し，『生活の再編成』因子と命 名した。因子II は，制約された状況下や慢性病 の影響を受けた対人関係における積極的・主体 的自己の価值に基づく行為と解釈し，『強い信念 に基づく振る舞い』因子とした，因子IIIは，慢 表2 社会生活満足度 $(n=89)$

\begin{tabular}{|c|c|c|c|}
\hline 項 & $\mathrm{n}$ & $\mathrm{M}$ & $\mathrm{SD}$ \\
\hline 仕事の満足度 & 89 & 3.8 & 1.0 \\
\hline 職場の理解度 & 86 & 4.2 & 1.2 \\
\hline 職場の人間関係満足度 & 83 & 3.8 & 1.0 \\
\hline $\begin{array}{l}\text { 身体が辛くて仕事を辞めたく } \\
\text { なる程度 }\end{array}$ & 89 & 3.9 & 1.1 \\
\hline 生計状態 & 89 & 3.2 & 0.9 \\
\hline
\end{tabular}




\begin{tabular}{|c|c|c|c|c|c|}
\hline 項 & 因子 I & 因子 II & 因子III & 因子IV & 因子V \\
\hline \multicolumn{6}{|l|}{ 「生活史の編みなおし」全体 $\quad \alpha=.73$} \\
\hline 「生活の再編成」 $\alpha=.83$ & & & & & \\
\hline $\begin{array}{c}\text { 項目 } 6 \text {. 健康や生活に役立つ情報をいつも敏感にキャッチ } \\
\text { している }\end{array}$ & -.79 & -.09 & -.16 & .24 & .09 \\
\hline $\begin{array}{c}\text { 項目 1. 透析をするようになってからいつそう家族との関係 } \\
\text { を大事にしている }\end{array}$ & -.68 & .23 & -.01 & .11 & -.12 \\
\hline $\begin{array}{c}\text { 項目 14. 家族にやってもらいたいことを, うまく伝えたり指 } \\
\text { 示することができる }\end{array}$ & -.55 & .26 & -.29 & -.06 & -.08 \\
\hline \multicolumn{6}{|l|}{ 「強い信念に基づく振る舞い」 $\alpha=.82$} \\
\hline $\begin{array}{l}\text { 項目 16. どんな状況にも順応して, 精神的ゆとりのある生 } \\
\text { 活を楽しむことができる }\end{array}$ & -.09 & .86 & .00 & .14 & -.10 \\
\hline $\begin{array}{c}\text { 項目 } 15 . \text { まわりの人達が自分とは違った考え方や偏見をも } \\
\text { つていても寛大さをもつてうまくやっていける }\end{array}$ & -.15 & .69 & -.27 & -.05 & -.23 \\
\hline $\begin{array}{c}\text { 項目 17. 状況や相手が異なっても, 自分の意見や振る舞い } \\
\text { 方を変えたりしない }\end{array}$ & .22 & .64 & -.14 & -.32 & .07 \\
\hline \multicolumn{6}{|l|}{ 「社会的地位・役割の維持」 $\alpha=.81$} \\
\hline $\begin{array}{c}\text { 項目 3. 仕事ひとすじに働いてキャリア(職歴)を維持してい } \\
\text { る }\end{array}$ & -.25 & .08 & -.80 & -.07 & -.02 \\
\hline $\begin{array}{c}\text { 項目 13. 職場では病人扱いされないように，明るく振る舞 } \\
\text { っている }\end{array}$ & -.07 & .06 & -.76 & .03 & -.09 \\
\hline $\begin{array}{c}\text { 項目 12. 仕事をやり遂げるためには残業や休日出勤なども } \\
\text { いとわずやりくりしている }\end{array}$ & .46 & .15 & -.60 & .21 & -.17 \\
\hline \multicolumn{6}{|l|}{ 「新役割の探求」 $\alpha=.80$} \\
\hline $\begin{array}{c}\text { 項目 5. 時間的なハンディを乗り越えるための資格や技術な } \\
\text { どを身に付けるようにしている }\end{array}$ & -.04 & -.17 & -.05 & .82 & -.04 \\
\hline $\begin{array}{l}\text { 項目 } 2 . \text { 自分の身体にあった労働環境や条件を積極的に整 } \\
\text { えている }\end{array}$ & -.11 & .29 & -.04 & .62 & .24 \\
\hline $\begin{array}{l}\text { 項目 } 7 \text {. 透析を始めて新しい目標をみつけることができたと } \\
\text { 思う }\end{array}$ & -.43 & .26 & .08 & .59 & -.13 \\
\hline \multicolumn{6}{|l|}{ 「自己開示」 $\alpha=.80$} \\
\hline $\begin{array}{c}\text { 項目 4. 家族や身内以外にはほとんど病気や透析のことは } \\
\text { 話さない }\end{array}$ & .27 & -.01 & -.01 & .11 & -.78 \\
\hline $\begin{array}{c}\text { 項目 9. 特定の仕事仲間や友人には自分の感情や気持ちを } \\
\text { 素直に表現できる }\end{array}$ & -.28 & .23 & -.17 & -.15 & -.66 \\
\hline $\begin{array}{c}\text { 項目 } 10 . \text { 透析を始めてからも他の人達との親密な関係を持 } \\
\text { てている }\end{array}$ & -.27 & .27 & -.12 & -.05 & -.59 \\
\hline 因子負荷量の二乗和 & 2.18 & 2.09 & 1.84 & 1.68 & 1.59 \\
\hline 因子の寄与率（\%） & 14.52 & 13.93 & 12.29 & 11.21 & 10.63 \\
\hline 累積寄与率（\%） & 14.52 & 28.45 & 40.74 & 51.94 & 62.57 \\
\hline
\end{tabular}

性病をもちながらも以前の職業生活における, その人の役割や他者からの評価を維持しようと する行為と解釈し, 『社会的地位・役割の維持』 因子とした．因子IVは，新たな価値観に基づい て自己の役割に活路を見いだそうとする主体的 自己の姿と解釈し, 『新役割の探求』因子とし た．因子Vは，いずれの項目も内面性の高い情
報開示の側面と考えられ, 対人関係における慢 性病の意味を受けとめて情緒面の調整をする行 為と解釈し, 『自己開示』因子とした。

\section{2 ）構成概念妥当性}

各因子の妥当性を確認するために，5因子の 標準因子得点と理論的に関係が予測される個人 
特性との関係を分析した(表4，5).

その結果，生活の再編成標準因子得点は，1 週間の透析回数が少ないほど, 仕事の満足度が 高いほど高得点の傾向にあったが, 一人暮らし $(\mathrm{F}(1,83)=5.41, \mathrm{p}<.05)$ や未婚者 $(\mathrm{F}(1$, $83)=4.53, \mathrm{p}<.05)$ では低得点の傾向にあっ た. よって社会的役割, 療養法に要する時間, 協力体制に必要な資源との関連が確認された。

第2の強い信念に基づく振る舞い標準因子得 点は, 職場の人間関係満足度が高いほど高得点 の傾向にあったことから，社会関係が関連して いた.

第3の社会的地位・役割の維持標準因子得点 は， 1 週間の労働日数 $(\mathrm{F}(1,80)=4.90, \mathrm{p}<.05)$ が週 6 日以上よりも週 5 日以下が, 年齢層 $(\mathrm{F}$ $(3,81)=4.05, \mathrm{p}<.01)$ の $35 \sim 39$ 歳よりも 45 ４9歳が，原疾患診断から透析導入迄の期間 $(\mathrm{F}(3,76)=7.77, \mathrm{p}<.001)$ が 1 年以下よりも 6 〜 10年が, 高得点の傾向にあった. このことか ら社会的地位・役割の維持は, 生涯発達段階や 社会的対応態勢の準備期間などの時機的・時間 的要因, 身体的要因と関連していた。

第4の新役割の探求標準因子得点は, 仕事の 満足度が低いほど高得点の傾向にあった。第 5
の自己開示標準因子得点は, 職場の理解度が高 いと認知しているほど高得点の傾向にあった. よってこれらは, 社会的役割, 社会関係と各々 関連していた.

5 因子標準得点との有意な関係が確認された 要因を総合すると, 生活史や生活の時間的要因, 家族や職場などの社会関係要因, 自己の社会的 役割要因, 社会活動に必要な身体的要因であっ た。これらは, 病みの軌跡理論における生活史 概念の 3 つの構成要素である, 生活史的時間, 自己概念, 身体と適合する. 以上の 5 標準因子 得点と理論的に予測された变数との関係から, 生活史の編みなおしの各因子は妥当性をほぼ有 していると考えられる.

つぎに再構成した 5 下位尺度間の関係をみる ために，相関係数および重回帰分析について分 析した結果，生活の編みなおし尺度は大きく2 つの方向づけを示していると推測した(表 6 , 図 1).すなわち生活の再編成，新役割の探求の 2 つは，生活史を手段的に補修ないし変更する方 向づけである. 他の 3 つすおちち強い信念に基 づく振る舞い, 社会的地位・役割の維持, 自己 開示は，生活史を情緒的に維持する方向づけで ある。

表4 標準因子得点と個人特性の相関関係（ケンドール順位相関係数）

\begin{tabular}{|c|c|c|c|c|c|}
\hline 標準因子得点名 & $\begin{array}{l}\text { 1) 透析回 } \\
\text { 数 / 週 }\end{array}$ & $\begin{array}{l}2 \text { 2) 就労日 } \\
\text { 数/週 }\end{array}$ & $\begin{array}{l}3 \text { ) 仕事の } \\
\text { 満足度 }\end{array}$ & $\begin{array}{l}\text { 4) 職場の } \\
\text { 理解度 }\end{array}$ & $\begin{array}{r}5 ） \text { 職場の } \\
\text { 人間関係 }\end{array}$ \\
\hline 因子 I 『生活の再編成』 & $-.21 *$ & .04 & $.22 *$ & .02 & .11 \\
\hline 因子 II 『強い信念に基づく振る舞い』 & -.10 & .12 & .02 & .08 & $.24 * *$ \\
\hline 因子III 『社会的地位・役割の維持』 & .05 & $-.21 *$ & .03 & .01 & 19 \\
\hline 因子IV 『新役割の探求』 & -.00 & .08 & $-.20 *$ & .09 & -.01 \\
\hline 因子V 『自己開示』 & .01 & .01 & .12 & $.25 * *$ & .13 \\
\hline
\end{tabular}

$* \mathrm{p}<.05 \quad * * \mathrm{p}<.01$

表5 標準因子得点と個人特性の関係（一元配置分散分布）

\begin{tabular}{|c|c|c|c|c|c|}
\hline 標準因子得点名 & 1) 年齢層 & $\begin{array}{l}\text { 2) 診断一 } \\
\text { 導入期間 }\end{array}$ & $\begin{array}{l}3 \text { ）同居家 } \\
\text { 族 }\end{array}$ & 4）結婚歴 & $\begin{array}{l}5 \text { ) 就労日 } \\
\text { 数/週 } \\
\end{array}$ \\
\hline $\begin{array}{l}\text { 因子 I 『生活の再編成』 } \\
\text { 因子 II 『強い信念に基づく振る舞い』 }\end{array}$ & & & $\begin{array}{l}\mathrm{F}=5.41 * \\
(\text { 有 }>\text { 無) }\end{array}$ & $\begin{array}{c}F=4.53 * \\
\text { (既婚 }>\text { 未婚) }\end{array}$ & \\
\hline $\begin{array}{l}\text { 因子III 『社会的地位・役割の維持』 } \\
\text { 因子IV 『新役割の探求』 }\end{array}$ & $\begin{array}{c}\mathrm{F}=4.05 * * \\
(45-9 \text { 才 }> \\
35-9 \text { 才 })\end{array}$ & $\begin{array}{c}\mathrm{F}=7.77 * * * \\
(6-10 \text { 年> } \\
1 \text { 年以下 })\end{array}$ & & & $\begin{array}{c}\mathrm{F}=4.90 * \\
(5 \text { 日以下> } \\
6 \text { 日以上 })\end{array}$ \\
\hline
\end{tabular}

$* \mathrm{p}<.05 \quad * * \mathrm{p}<.01 \quad * * * \mathrm{p}<.001$ 
表6 各下位尺度と全体の相関関係（ピアソン積率相関係数）

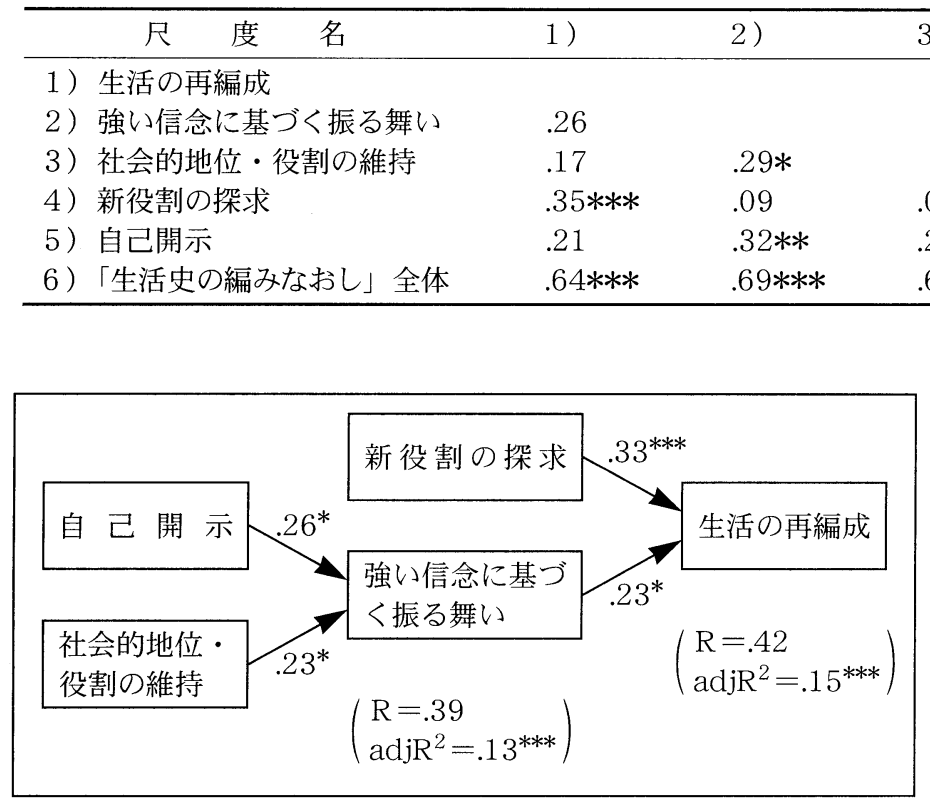

図 1 下位尺度間の関係（パス・ダイアグラム）

$* \mathrm{p}<.05$ ** $\mathrm{p}<.01$ **** $\mathrm{p}<.001$
3)

.09

$.24 * \quad .04$

$.63 * * * \quad .52 * * * \quad .60 * * *$

有していると考えられた.

以上のことから本尺度の構成 概念妥当性は, ある程度支持さ れることが確認された。

\section{3 ）信頼性}

本尺度の信頼性の分析を行つ た結果，2項目を除外した全 15 項目の内部整合性は.73 (Cronbach’s $\alpha$ ) であった. ま た，因子分析によって再構成し

最後に，再構成した尺度を理論的に設定した 尺度構成と比較した(表7)。その結果，社会的 地位・役割の維持という下位尺度が新たに独立 していた。また他の4下位尺度にそれぞれ含ま れる項目を理論的設定の上位尺度レベルで比べ ると，3項目を除いては一致した．4下位尺度か ら5下位尺度への変更を考慮すると，理論的な 尺度構成は因子分析の結果とある程度整合性を
た各下位尺度の信頼性を分析した結果，5下位 尺度の各々の内部整合性は .80〜.83であった (表3，7）。尺度全体および各下位尺度の信頼性 は.70以上であった.したがって本尺度の信頼性 は，ある程度支持されることが確認された。

\section{VI. 考察}

先行研究において, 生活史の編みなおし概念

\section{表7 尺度構成の比較}

\begin{tabular}{|c|c|c|c|c|c|}
\hline \multicolumn{3}{|c|}{ 理論的に設定した尺度：4下位尺度 17 項目 $\alpha=.68$} & \multicolumn{3}{|c|}{ 最終的な尺度：5下位尺度 15 項目 $\alpha=.73$} \\
\hline 上位尺度 & 下位 尺度 & 項 目 & 上位尺度 & 下位尺度 & 項目 \\
\hline \multirow{3}{*}{$\begin{array}{l}\text { 病いと共に生活 } \\
\text { するための調整 } \\
\alpha=.70\end{array}$} & $\begin{array}{l}\text { 病と共存するため } \\
\text { の価値観の転換 } \\
\alpha=.68\end{array}$ & $\begin{array}{l}\text { 1), 3), 5), 7), } \\
8), 16)\end{array}$ & \multirow{2}{*}{$\begin{array}{l}\text { 生活史を手段的 } \\
\text { に補修ないし変 } \\
\text { 更する方づけ }\end{array}$} & $\begin{array}{l}\text { 生活の再編成 } \\
\alpha=.83\end{array}$ & 1), 6), 14) \\
\hline & \multirow{2}{*}{$\begin{array}{l}\text { 病の変化に対応し } \\
\text { た生活の再編成 } \\
\alpha=.70\end{array}$} & \multirow{2}{*}{$\begin{array}{l}\text { 2), 6), 11), } \\
\text { 12), 14) }\end{array}$} & & $\begin{array}{l}\text { 新役割の探求 } \\
\alpha=.80\end{array}$ & $2), 5), 7)$ \\
\hline & & & \multirow{4}{*}{$\begin{array}{l}\text { 生活史を情緒的 } \\
\text { に維持する方向 } \\
\text { づけ }\end{array}$} & 強い信念に基づく & 15), 16), 17) \\
\hline \multirow{4}{*}{$\begin{array}{l}\text { 他者と共に生活 } \\
\text { するための調整 } \\
\alpha=.67\end{array}$} & 関係性保存の手段 & & & 振る舞り & \\
\hline & $\begin{array}{l}\text { 的調整 } \\
\alpha=.79 \\
\end{array}$ & 4), 9), 10) & & $\begin{array}{l}\text { 社会的地位 - 役割 } \\
\text { の維持 } \quad \alpha=.81\end{array}$ & 3), 12), 13) \\
\hline & \multirow{2}{*}{$\begin{array}{l}\text { 社会的相互作用へ } \\
\text { の新たな情緒的配 } \\
\text { 慮 } \alpha=.57\end{array}$} & \multirow{2}{*}{ 13), 15), 17) } & & 自己開示 $\alpha=.80$ & 4), 9), 10) \\
\hline & & & \multicolumn{2}{|l|}{ 削除項目 } & 8), 11) \\
\hline
\end{tabular}


表8 既存尺度との比較

\begin{tabular}{|c|c|c|c|c|}
\hline 尺度 & $\begin{array}{c}\text { 本尺度 } \\
\text { 生活史の編みなおし }\end{array}$ & $\begin{array}{c}\text { 対処様式測定法 } \\
\text { (WCQ) }\end{array}$ & $\begin{array}{c}\text { The Psychosocial } \\
\text { Adjustment to Illness } \\
\text { Scale (PAIS) }\end{array}$ & 病を持ちながらの生活管理（DLA） \\
\hline 開 発 者 & 筆者（1996） & \begin{tabular}{|l|} 
Lazarus, R.S. \& \\
Folkman, S. (1984) \\
\end{tabular} & Derogatis, L.R. (1978) & 黒田裕子（1991） \\
\hline 評 定 法 & 5 件法: $1 \sim 5$ 点 & 4 件法: $0 \sim 3$ 点 & 4 件法: $0 \sim 3$ 点 & 5 件法: $1 \sim 5$ 点 \\
\hline 理 & $\begin{array}{l}\text { Corbin \& Strauss } \\
(1988) \\
\text { 病みの軌跡理論 }\end{array}$ & $\begin{array}{l}\text { ストレス・ } \\
\text { コーピング理論 }\end{array}$ & & $\begin{array}{l}\text { Strauss (1984) 慢性病者が日常生活で出 } \\
\text { 会う多様な8つの鍵問題 } \\
\text { Henderson (1966) } 14 \text { 日常生活活動の } \\
\text { 構成要素 }\end{array}$ \\
\hline 下位尺度 & $\begin{array}{l}\text { 1）生活の再編成 } \\
\text { 2）強い信念に基づ } \\
\text { <振る舞い } \\
\text { 3）社会的地位・役 } \\
\text { 割の維持 } \\
\text { 4）新役割の探求 } \\
\text { 5）自己開示 }\end{array}$ & 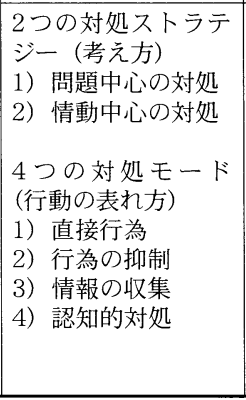 & $\begin{array}{l}\text { 1）ヘルスケアの方向性 } \\
\text { 2) 職業的環境 } \\
\text { 3）家庭環境 } \\
\text { 4）性的関係 } \\
\text { 5）拡大家族の関係性 } \\
\text { 6）社会環境 } \\
\text { 7）心理的苦痛 }\end{array}$ & 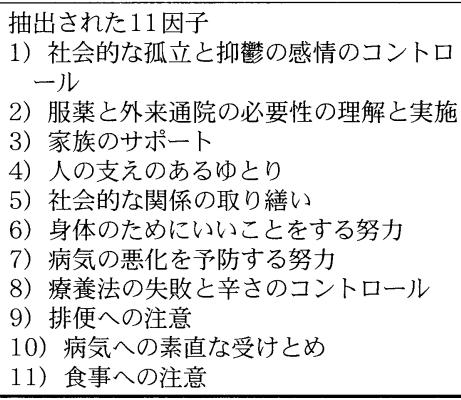 \\
\hline
\end{tabular}

を測定した尺度は見当たらない。しかし本尺度 の構成概念は, 慢性病がもたらすストレスへの 対処行為, あるいは心理社会的適応について視 点を変えて捉えようとしたものである. そこで, 関連する概念をもつ既存の尺度について比較検 討した(表8).

まず，本尺度の対処行為という内容に関連す るものに, Lazarus \& Folkman(1984)の対処 様式測定法 ${ }^{18)}$ (WCQ と略す)がある.つぎに本 尺度の慢性病への心理社会的適応という内容に 関連するものに, Derogatis(1978)の病気への 心理社会的適応度(PAIS と略す) ${ }^{19)}$ がある。 そ して本尺度の慢性病をもちながら社会活動をす る生活者という内容に関連するものに, 黒田 (1991)の病をもちながらの生活管理尺度 ${ }^{20)}$ (DLA と略す)がある。DLAは, Strauss (1984) らの説く慢性病者の8つの鍵問題 ${ }^{14)}$ 基盤にしている. 因子分析で抽出された 11 因子 からも, 病みの軌跡の管理に必要とされる病気, 日常生活, 生活史の主要な3つの仕事を包括的 に網羅していると思われる。

以上の 3 尺度と比較すると，本尺度の構成は 手段的, 情緒的対処の 2 領域を有しており, WCQの構成と類似している. しかしWCQの構 成概念は，慢性病や生活史という特定の文脈を
含んでおらず，WCQだけでは慢性病に関する心 理社会的問題や適応の様相は明らかにならない. また慢性病をもつ生き方への支援を検討するた めに必要な情報も得られないと考える.

一方, PAIS とDLAの構成概念は, 慢性病に よって生じる心理社会的問題を含む点で, 本尺 度の構成概念との類似性は高い.

本尺度の生活の再編成は, DLAの〈家族のサ ポート〉, PAISの〈家庭環境〉と, 第2の強い信 念に基づく振る舞いはDLAの〈社会的な孤立と 抑うつ感情のコントロール〉, PAISの〈心理的苦 痛〉と共通する部分をもつと考えられる. 第3の 社会的地位・役割の維持は, DLAの〈社会的な 関係の取り繥い〉, PAISの〈職業的環境〉と, 第 5 の自己開示は，DLAの〈人の支えのあるゆと り〉, PAISの〈社会環境〉と関連していると考え られる.

第4の新役割の探求と関連する下位尺度は見 当たらなかった. これは自分らしい生活への指 向, あるいは人生の未来への方向づけが最も強 く現れている下位尺度と考える。従来，日本の 透析患者に特有に見られる現象として「消極的 適応」や，自己の内面生活の充実や向上を求め る人は少ないと見られていた ${ }^{3)}$ が，新役割の探 求は積極的適応の側面もあることを示唆してい 
る.

他の 3 尺度は現在の認知や対処を測定してお り, 未来への方向づけのような時間的展望を含 んでいなかった.しかしながらPAIS とDLAは， 単独で慢性病者の生活全体像を捉えることがで きると思われる，本尺度は，透析者の医療者と の関係や日常生活における病気の管理など, 生 活史の編みなおしに関連する内容を含んでおら ず，今後再検討する必要がある.

またCorbin \& Strauss (1988)が, 認知的情 緒的な生活史的仕事の属性として, 振り返り (review), 維持 (maintenance), 補修 (repair), 変更 (alteration) をあげている ${ }^{5)}$. 本尺度の 5 下位尺度は, 維持, 補修, 変更の 3 つ属性と同様の方向づけを含んでいるが，振り 返りは含んでいない，本尺度は，透析者が過去 を振り返り, 経験への意味づけを指針として展 開する行為に焦点を当てたものである. 振り返 りについては, 既存の尺度 ${ }^{21)}$ を使用することを 意図していたので本尺度には含めなかった。し たがって, 本尺度を単独で用いて, 透析者の生 活史の編みなおし全体像を理解するのは，かな り限界が大きいと思われる。

\section{VI. 今後の課題}

本尺度は, 信頼性, 妥当性共にある程度支持 されることが確認されたが, 対象者数は89名と 少なく本研究の検定結果を一般化するには限界 が大きいと考える. また生活史の編みなおし度 をグループ間で比較することは可能と考えるが, 個人の評価に用いるには今後の検討が必要であ る. 信頼性, 妥当性を増すためには, 下位尺度 の概念化を再検討し項目数を増やすこと, 再テ スト法による検討などが必要と考える. しかし 有用性の点からは下位尺度を少なくし全体の項 目数を短縮することも必要である.したがって, 上位尺度をさらに設定するなど尺度構成を再検 討したうえで，尺度全体を洗練する必要性が示 された.

\section{謝辞}

本研究において御協力いただきました東京都 および全国腎臟病患者連絡協議会の関係者, 各
病院透析施設の透析者およびスタッフの皆様, そして保健・看護研究者の皆様に心より感謝申 し上げます。また研究の御指導をいただきまし た日本赤十字看護大学黑田裕子先生に深謝致し ます.

本研究は，1996年度日本赤十字看護大学大 学院看護学研究科修士課程に提出した修士論文 の一部に加筆・修正を加えたものである.

\section{文献}

1) 日本透析医学会 : わが国の慢性透析療法の 現況, 日本透析医学会, 1995.

2 ）全国腎臟病患者連絡協議会・社団法人日本 透析医会・財団法人統計研究会：1991年 度血液透析患者実態調査報告書, 全国腎臓 病患者連絡協議会, 1992 .

3 ）志自岐康子・中西睦子：透析患者の生活適 応に関する研究一セルフケアの観点からみ たニード充足範囲とその評価について一, 日本赤十字看護大学紀要, 6, 30-40, 1992.

4) 朝倉隆司：慢性疾患患者・障害者の職業生 活の再建とその要因について一人工透析患 者の場合一, 労働研究所報, 47-67, 1987.

5 ) Corbin, J.M. \& Strauss, A.L. : Unending work and care, Jossey-Bass Inc., 1988.

6 ) Baldree, K.S., Murphy, S.P., \& Powers, M.J. : Stress identification and coping patterns in-patients on hemodialysis, Nursing Research, 31 (2), 107-12, 1982.

7 ) Gurklis, J.A., \& Menke, E.M. : Chronic hemodialysis patients' perceptions of stress, coping, and social support, Anna Journal, 22 (4), 381-8, 1995.

8 ) Hrobsky, D.M. : Choice of coping strategies in hemodialysis patients : their effectiveness in relation to compliance outcomes, psychosocial adjustment, and a physiological indicator of stress, Unpublished Ph. D., New School For Social Research, 1991.

9) Somer, E., \& Tucker, C.M. : Patient life engagement, spouse marital adjustment, and dietary compliance of hemodialy- 
sis patients, Journal of Compliance In Health Care, 3 (1), 57-65, 1988.

10) Sensky, T., Leger, C., \& Gilmour, S. : Psychosocial and cognitive factors associated with adherence to dietary and fluid restriction regimens by people on chronic haemodialysis, Psychotherapy \& Psychosomatics, 65 (1), 36-42, 1996.

11) Kimmel, P.L., Peterson, R.A., Weihs, K.L., Simmens, S.J., Boyle, D.H., Umana, W.O., Kovac, J.A., Alleyne, S., Cruz, I., \& Veis, J.H. : Psychologic functioning, quality of life, and behavioral compliance in patients beginning hemodialysis, Journal of the American Society of Nephrology, 7 (10), 2152-2159, 1996.

12) Mapes, D.L. : Self-management compliance and quality of life in chronic hemodialysis patients, Unpublished D.N.S., University of California, San Francisco, 1991.

13) Devins, G.M. : Illness intrusiveness and the psychosocial impact of lifestyle disruptions in chronic life-threatening disease, Advances in Renal Replacement Therapy, 1 (3), 251-63, 1994.

14) Strauss, A.L., Corbin, J., Fagerhaugh, S., et al. : Chronic illness and the Quality of life (2nd ed.), 1984, 南裕子・木下康 仁・野嶋佐由美訳, 慢性疾患を生きるケア とクォリティ・ライフの接点, 医学書院, 1987.
15) Woog, P. (ed.) : A nursing model for chronic illness management based upon the trajectory framework, 1992, 黒江ゆり子・市橋恵子・宝田穂訳, 慢性疾 患の病みの軌跡 コービンとストラウスら による看護モデル，医学書院, 1995.

16) Goffman, E. : Stigma : Notes on the management of spoiled identity, 1963, 石黒 毅訳，スティグマの社会学一烙印を押され たアイデンティティ, せりか書房, 1987.

17）吉田富二雄 : 第6章 心理尺度の信頼性と 妥当性一尺度が備えるべき基本的条件一, 堀洋道・山本真理子・松井豊編, 心理尺度 ファイル—人間と社会を測る一，621-635， 垣内出版, 1994.

18) Lazarus, R. \& Folkman, S. : Stress, appraisal, and coping, 1984, 本明寛・春木 豊・織田正美監訳，実務教育出版，1991.

19) Derogatis, L.R. : Psychosocial adjustment to illness scale, Clinical Psychosomatic Research, Baltimore, 1975.

20）黒田裕子：虚血性心疾患を持ちながら生活 する男性のクオリティ・オブ・ライフを測 定する質問紙の開発に関る研究一病いをも ちながらの生活管理の質問紙に焦点を当て て一, 日本看護科学会誌, 11 (2), 1-16, 1991.

21) Fife, B.L. : The measurement of meaning in illness, Social Science \& Medicine, 40 (8), 1021-1028, 1995. 